\title{
Congenital T-Cell Immunodeficiency
}

National Cancer Institute

\section{Source}

National Cancer Institute. Congenital T-Cell Immunodeficiency. NCI Thesaurus. Code C27872.

A broad classification of inherited disorders presenting at birth that affect the cellmediated aspect of the immune response. Circulating numbers of $\mathrm{T}$ lymphocytes are decreased or ineffective. 